\title{
'Now Shall I See the Fall of Babylon': The Spanish Tragedy as a Reformation Play of Daniel
}

\author{
FRANK R. ARDOLINO
}

During the sixteenth century, the Book of Revelation served as the primary theological source for Reformation attacks on the Pope as Antichrist and the Roman Catholic Church as the Whore of Babylon, the tyrannical enslaver of the beleaguered Protestants, who were compared to the Israelites during the Babylonian captivity imposed by King Nebuchadnezzar. Although not as popular a subject for interpretation as Revelation, which received eighteen commentaries, ${ }^{1}$ the Book of Daniel was given an important supporting role by Protestant reformers such as Joye, Calvin, Broughton, and Brightman in the creation of a body of apocalyptic exegesis "calling for... divine judgment on the present powers of the world and their overthrow by the heavenly armies that will install on earth the true city of God." 2 Throughout the Reformation, the prophecies contained in Daniel 2 and 5 and in Revelation 14:8, 17:5, 18:2, 10, 21 were invoked to predict the fall of Babylon, the city ruled by the Antichrist and most frequently identified as Rome and Spain.

In Daniel 2, King Nebuchadnezzar has a dream which he has forgotten, and so he orders his soothsayers to reconstruct and interpret it. When they fail, Daniel, with the help of God who reveals "this secret... mystery in a vision," 3 describes and interprets the King's dream of a composite beast with a golden head, silver breast and arms, brazen belly and thighs, and iron legs - which is smashed by a stone. The four metals represent four empires (Babylon, Persia, Greece, and Rome) which will rule the world and be overturned successively until the last and worst, Rome, will be defeated by Christ's kingdom "which shal never be destroyed."

Chapter five presents the most dramatic scene in the Book of Danicl when Belshazzar, the last of the Babylonian monarchs, holds a drunken feast during which the fingers of a man's hand appear and write on the 
wall four words which no one can understand. Again, Daniel interprets the mystery, explicating each of the four words which predict that Babylon will fall to the Persians (5:25-28). That night Daniel's interpretation is fulfilled when Belshazzar is slain and Babylon conquered by Darius - acts which prefigure the overthrow of the evil empire of Rome: "In the destruccion of the first Monarchye lerne the figure of the destruccion of the...last Monarchye... for right just causes" (Joye 64v).

In the final chapter of Daniel after the angel reveals the vision of the Last Judgment when "[some] people shal awake ... to everlasting life, and some to shame and perpetual contempt" (12:1-2, 365v), he tells Daniel to "shut up the wordes, and seale the boke til the end of ... time" (12:4). When Daniel asks for more information, the angel replies that "the wordes are... sealed [and] ... none of the wicked shal have understanding: but the wise shal understand" (12:10).

For Protestant reformers the sealing of the prophetic truths in a book after they already have been declared serves as a metaphor for religious mysteries which are revealed to the initiated audience, namely, the Protestant faithful, and at the same time concealed from the uninitiated or profane audience of Catholics. George Joye is emphatic about the differences in understanding between the two audiences: "To shut up the wordis and seal ... the boke is to hyde ... wordis and secrets from the ungodly filthy swine and dogges that thei understand them not.... To you [the elect] is geven to know but not to them" (238r). Thomas Brightman concludes that the command to seal the truths is actually an incentive to the faithful to strive to understand these mysteries because "seeing by their goodly labour and diligence, God doth make over to the godly all his mysteries and secrets."5 Thus for the initiated, those who can interpret the mysteries, the pose of secrecy at the conclusion of Daniel can be seen as a literary fiction; however, these same truths remain concealed from the unbelievers, as Calvin declares, "because they seying would not see: and it is as if one should reach unto them a booke that were ... in a straunge... toung." 6

In their praise of the consolation afforded the faithful by the Book of Daniel, the commentators place the work within a dramatic context. Brightman says reading Daniel is like seeing a play in which "the lovelie face of ...truth... [is] brought upon the stage in open view" (10), while Calvin praises "the goodnes of God that shyneth forth in the end of the tragedy" (A4r). Joye applies the theatrical metaphor to the Book of Daniel in a manner similar to the context created by Hieronimo's revenge play-within-the-play when the intended victims are killed for real while they imagine they are acting in a marriage playlet: "cryst is even now preparinge 
these judgement seatis ... to destroy these wicked Anticrysten hornes ... for this is ... the ende of this tragedye.... thus go they [the wicked] out of their playe even when thei thinke to be but in middis of their matter" (110v).

In their comparisons of Daniel to a play, the commentators draw upon the tradition of dramatizing scenes from the Book of Daniel, which originated in the liturgical celebration of the Ordo Prophetarum and continued in the twelfth century with Hilarius' Historia de Daniel Repraesentanda and the Beauvais Danielis Ludus. Throughout the Reformation, dramatizations of episodes from Daniel and apocryphal stories of Daniel's rescuing Susanna from the calumny of the elders and outwitting the priests of Bel were given political import. Robert Garnier, whose Roman tragedy Cornelie Kyd translated, wrote Les Juifves, tragedie (Paris, 1583), in which he compares the turmoil resulting from Nebuchadnezzar's pride to the horrors of the French civil wars caused by the replacement of God with intestine sects. ${ }^{7}$ In The Comody Of the most vertuous and Godlye Susanna (1578), Thomas Garter equates Daniel's vindication of Susanna with the divine preservation of Queen Elizabeth and England:

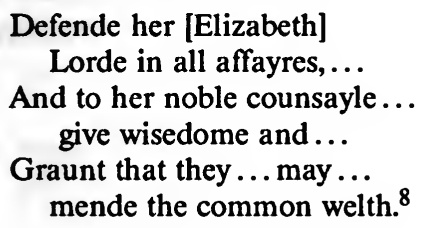

Thus when Kyd wrote The Spanish Tragedy, there existed dual traditions of dramatic representation and Protestant exegesis of the Book of Daniel with which at least some segments of his audience would have been familiar. It is my contention that Kyd conceived of The Spanish Tragedy as a sixteenth-century play of Daniel intended to represent to English audiences the fall of Babylon-Spain. The Spanish Tragedy parallels the Book of Daniel in Kyd's presentation of three plays-within-the-play that are identified as mysteries with covert political and eschatological meanings understood only by the initiated (I.i.90; I.iv.139; III.xv.29); and in Hieronimo's achievement of revenge in a climactic playlet which is analogous to Belshazzar's feats in Daniel 5. In short, The Spanish Tragedy is a mystery play in which Hieronimo, the Danielic figure, the judge, the bearer of the sacred name (hieros nym), Anglophile representative of God's will at the court of Babylon-Spain, author, actor, and revenger, creates the Spanish tragedy and the English comedy. 


\section{2 / Renaissance and Reformation}

The most illustrative example of a play-within-a-play being defined as a mystery occurs at I.iv.139 when Hieronimo presents the historical masque to the assembled Iberian dignitaries. After its completion, the Spanish King says "Hieronimo this masque contents mine eye, / Although I sound not well the mystery."9 Hieronimo responds that the playlet has shown three historical events when England defeated Portugal (twice) and Spain (once), whereupon the Spanish King and Portuguese ambassador apply these events to the current context of Spain's defeat of Portugal. The King says that the sting of Portugal's recent defeat should be somewhat lessened by its awareness of its past defeats by England, but the Portuguese representative ironically reminds Spain that it too has lost to England in the past (147-71).

Hieronimo's historical masque raises an important question concerning the interpretation of symbolic dramatic productions. Ostensibly, he has presented the masque to celebrate the Spanish victory, but each historical incident shows England conquering the Iberian countries. As Eugene Hill has explained, the Elizabethan theater audiences were expected to recognize that the Iberian interpretations of the masque are inadequate, because they apply past events to their current reality and ignore the celebration of England's triumphs:

For the Spanish King "little England"... is peripheral to the meaning of the dumb show; but to the English audience it is the central agent of the dumb show - and of The Spanish Tragedy.... Hieronimo with his playlet ... hints at... English dominance. ${ }^{10}$

The real mystery of the masque - its hidden political meaning - escapes the blinded onstage audience but not Kyd's theater audiences who would interpret the mystery from the English perspective.

The historical masque serves as proleptic to Hieronimo's revenge playlet ostensibly intended to celebrate the marriage of Bel-imperia and Balthazar, the dynastic union of Spain and Portugal, but actually directed toward the accomplishment of his revenge. The ill-fated marriage feast at which the murderous "Soliman-Perseda" playlet is enacted parallels Belshazzar's feats during which the fall of Babylon is prophesied by the mysterious handwriting on the wall. Just as Daniel prophesied the fall of Babylon in his interpretation of Nebuchadnezzar's dream of the metallic beast and the enigmatic writing at Belshazzar's feast, so too Hieronimo proclaims, before the performance of the revenge playlet, the destined fall of England's Catholic rival Spain: "Now shall I see the fall of Babylon, / Wrought by 
the heavens in this confusion" (IV.i.195-96). However, unlike Daniel, Hieronimo effects the fall when he creates the revenge playlet in which the heirs to the Iberian thrones are killed.

When Hieronimo stipulates that the playlet shall be acted in four tongues - Greek, Italian, Latin, and French - Balthazar rightly objects that "this will be a mere confusion" (IV.i.180), ironically echoing Hieronimo's prediction of Babylon-Spain's fall "wrought by the heavens in this confusion." S. F. Johnson has demonstrated that Kyd conflates the Babylon reference into a dual image of the fall of the Babylonian empire and the toppling of the Tower of Babel, which resulted in the confusion (Babel-babble) of tongues. ${ }^{11}$ As Peter Goodstein has noted, Prince Balthazar becomes an analogue to King Belshazzar "who saw the incomprehensible handwriting on the wall. Prince Balthazar calling the play-within-a-play 'a mere confusion' that will hardly be understood is analogous to the Babylonian's reaction to the words 'Mene, Mene, Tekel Upharsin."'12 But Hieronimo, the Danielic Vindicta Dei, is the decipherer of the confusion, the interpreter of the mystery playlet with the hidden meanings. The contrast between Danielic prophetic awareness and Babylonian confusion recalls Sheltco à Geveren's declaration that "Babylon received a fit name ... because in her there was made a confusion of tongues... and meere confusion in deede. . $" 13$

The sundry tongues motif also establishes a sense of the passage of the four doomed empires described in Daniel 2 and 7 as the Babylonian, Medo-Persian, Greek, and Roman. In The Spanish Tragedy Spain and Portugal are considered collectively as the contemporary Babylon and are represented by Lorenzo, Balthazar, and Castile, who are killed during and immediately after the playlet. Within the playlet, Hieronimo speaks Greek, and the Roman Empire and Catholic Church are represented by Lorenzo, who speaks Latin, and Balthazar, who performs double duty, so to speak, by speaking Italian and by playing the role of Soliman, the perfidious ruler of Turkey, whom Kyd substitutes for the Danielic Persian empire. In addition, Bel-imperia speaks French, the language of the Catholic country that carried out the infamous massacre in Paris on St. Bartholomew's day in 1572. Ironically, the attack on the French Huguenots was initiated during the celebration of the marriage of the Protestant Henry of Navarre to Marguerite de Valois, the daughter of Catherine de Medici, Queen mother of France. Hieronimo hints that he will be turning the tables in his wedding playlet after Lorenzo says that he has seen tragic plays enacted "In Paris, 'mongst the French tragedians" (IV.i.168). Hieronimo ominously responds: "In Paris? mass, and well remembered!" (169). The French tragedians, that 
is, the Catholics, produced tragic consequences for the Huguenots, but now Hieronimo, the Anglophile justice-figure, will produce tragic results for the empires represented in the playlet.

Kyd indicates that England is the divinely-favored nation that will succeed the fallen empires through the note directly before the enactment of the playlet that "this play of Hieronimo in sundry languages, was thought good to be set down in English ..., for the easier understanding to every public reader." The translation of the foreign languages into English signifies the passage from Babylonian confusion to the clarity of English, a process effected by God, "the most just translatour and changer of realmes" (Joye 64r). As Eugene Hill has remarked: "The playlet is an enacted pun on translation in different senses and different media. The real 'passing' involved in the translatio imperii - to England, to English" (163). In Kyd's recreation of Pentecostal inspiration, Hieronimo, the namesake of St. Hieronymus or Jerome, translates the foreign Catholic languages into "our vulgar tongue" (IV.iv.75) of English.

After his explanation of his reasons for the vengeance exacted in the playlet, Hieronimo bites out his tongue in allegiance to his vow of secrecy: "But never shalt thou force me to reveal / The thing which I have vow'd inviolate:" (187-88). In their insistence that Hieronimo reveal more about the playlet even after he has explained its meanings to them, the Iberian audience members serve as graphic examples of the uninitiated who

were so blinded, that in seeing they should not see.... If any man say, read thys, he will say the booke is sealed, I cannot: or let the booke be opened and all... shalbe as it were blynde.... there is a covering cast over their eyes... that they should be blinde in the most cleare light.... (Calvin 79v)

However, to the initiated theater audience, Hieronimo's "closing of the book" is a signal to go beyond the ignorant onstage audience to an understanding of the play's Danielic context.

As the related subtexts reveal, The Spanish Tragedy is much more than a blood revenge tragedy intended to attract Elizabethan audiences through its gory and sensational actions. Rather it is a learned, apocalyptic, and syncretistic mystery play, containing motifs which are concerned with the simultaneous revelation and concealment of hidden political and eschatological meanings. Moreover, these meanings are directly related to Kyd's conception of The Spanish Tragedy as a Reformation play of Daniel in which the sacred judge Hieronimo predicts and brings about the "fall of Babylon" 
at a wedding celebration analogous to Belshazzar's feast and thus effects the destiny announced by Revenge at the outset of the play.

\section{University of Hawaii}

\section{Notes}

1 Richard Bauckham, Tudor Apocalypse: Sixteenth-Century Apocalypticism, Millennarianism and the English Reformation from John Bale to John Foxe and Thomas Brightman (Appleford, England: Sutton Courtenay Press, 1978), p. 137.

2 Florence Sandler, "The Faerie Queene: An Elizabethan Apocalypse," The Apocalypse in English Renaissance Thought and Literature: Patterns, Antecedents and Repercussions, eds. C. A. Patrides and Joseph Wittreich (Ithaca, N.Y.: Cornell University Press, 1984), p. 158.

3 George Joye, The exposicion of Daniel the Prophete... (Geneva, 1545), f. 25r.

4 The Geneva Bible: A Facsimile of the 1560 Edition, ed. Lloyd E. Berry (Madison, Wisconsin: University of Wisconsin Press, 1969), 2:44, f. 357r. All quotations of the Bible are from this edition.

5 Thomas Brightman, A Most Comfortable Exposition ... of Daniel... (Amsterdam, 1635), p. 73.

6 John Calvin, Commentaries of that divine John Calvine, upon the Prophet Daniell, tr. Arthur Golding (London, 1570), f.. 8r.

7 J. S. Street, French Sacred Drama From Bèze to Corneille: Dramatic Forms and Their Purposes in the Early Modern Theatre (Cambridge: Cambridge University Press, 1983), pp. 80-84.

8 Thomas Garter, The Comody of the most vertuous and Godlye Susanna (Oxford: Malone Society Reprint, 1936), 1434-36, sig. F3r.

9 Thomas Kyd, The Spanish Tragedy, ed. Philip Edwards (London: Methuen, 1959), I.iv.138-39; the play is cited parenthetically from this edition.

10 Eugene Hill, "Senecan and Vergilian Perspectives in The Spanish Tragedy," English Literary Renaissance 15 (1985): 160.

11 S. F. Johnson, "The Spanish Tragedy, or Babylon Revisited," Essays on Shakespeare and Elizabethan Drama in Honor of Hardin Craig, ed. Richard Hosley (Columbia, Missouri: University of Missouri Press, 1962), p. 29.

12 Peter Goodstein, “Hieronimo's Destruction of Babylon," English Language Notes 3 (1966): 173.

13 Sheltco à Geveren, Of the End of this Worlde, and second comming of Christ ..., tr. Thomas Rogers (London, 1589), f. 36r. 